\title{
Cretaceous biota of the Triângulo Mineiro region (Brazil): A review of recent finds
}

\author{
Biota cretácica de la región del Triângulo Mineiro (Brasil): \\ Revisión de hallazgos recientes
}

\author{
C. R. A. Candeiro ${ }^{1}$
}

\begin{abstract}
The Bauru Group (Adamantina, Uberaba, and Marília Formations) crop out in the Triângulo Mineiro region, Minas Gerais State, Brazil, and yield a rich continental biota. Invertebrate and vertebrate taxa from underlying and overlying strata, as well as biostratigraphical correlations with other fossil sites in Argentina, suggest an Upper Cretaceous age for this biota. The diversity of the fossil assemblage recorded in these formations is summarized here and includes: frogs, lizards, crocodiles, titanosaurs, abelisaurid and carcharodontosaurid dinosaurs. This fossil assemblage provides important clues to understand faunas from other southern landmasses, particularly those from the Cretaceous of the African continent.
\end{abstract}

Key-words: Upper Cretaceous, Triângulo Mineiro, Adamantina, Uberaba, and Marília Formations, biota, Brazil.

\section{RESUMEN}

Los afloramientos del Grupo Bauru (formaciones Adamantina, Uberaba y Marília) en la región del Triângulo Mineiro, Provincia de Minas Gerais, Brasil, posee un rico contenido de biota continental. Los taxa de invertebrados y vertebrados de estos estratos, así como las correlaciones biostratigráficas con otros yacimientos fósiles de Argentina, sugieren una edad del Cretácico Tardío. La diversidad de la asociación fósil registrada en las formaciones del Triângulo Mineiro se resume en el presente trabajo e incluye: sapos, lagartos, tortugas, cocodrilianos, titanosaurideos, dinosaurios abelisaurideos y carcharodontosaurideos. Esta asociación es importante para la comprensión de las faunas del sur de América y también de las del Cretácico de África.

Palabras-clave: Cretácico superior, Triângulo Mineiro, formaciones Adamantina, Uberaba y Marília, biota, Brasil.

\section{Introduction}

The Triângulo Mineiro region $\left(19^{\circ} 11^{\prime}-10^{\prime \prime}\right.$ and $19^{\circ}-49^{\prime} 59^{\prime \prime} \mathrm{S}, 47^{\circ} 30^{\prime}$ and $48^{\circ} 19^{\prime} 24^{\prime \prime} \mathrm{W}$ ) occupies approximately $3.265 \mathrm{~km}^{2}$, and is located in western Minas Gerais State, Brazil (fig. 1). The region contains one of the richest Upper Cretaceous continental biota known in the country (see table 1). Fossil bearing strata of fluvial, eolian and lacustrine sediments, are exposed in the Triângulo Mineiro region, which includes Campina Verde, Monte Alegre, Prata, Uberaba, and Uberlândia municipalities.

Vertebrate bones were first discovered in late 1940 near Uberaba Town; during the following decade, Llewellyn Ivor Price re-studied the vertebrate-bearing deposits of the Triângulo Mineiro region focusing on the Adamantina and Marília Formations. The Adamantina, Uberaba, and Marília Formations from Triângulo Mineiro have yielded abundant dinosaur bones, including partial skeletons, eggs, and teeth associated with remains of other macro and microvertebrate assemblages (Bertini et al., 1993; Dias-Brito et al., 2001).

The most common taxa is reptilian, and occurs in the Adamantina and Marília formations of Campina Verde, Monte Alegre, Prata, and Uberlândia municipalities. The Uberaba Formation, restricted to the Triângulo Mineiro region, includes only a few vertebrate taxa. In the Uberaba Formation scarce

\footnotetext{
${ }^{1}$ Laboratório de Macrofósseis, Departamento de Geologia, Universidade Federal do Rio de Janeiro (UFRJ), Av. Brig. Trompsky, S/N, Cidade Universitária, Rio de Janeiro, RJ, Brazil. E-mail: candeiro@ ras.ufu.br.
} 

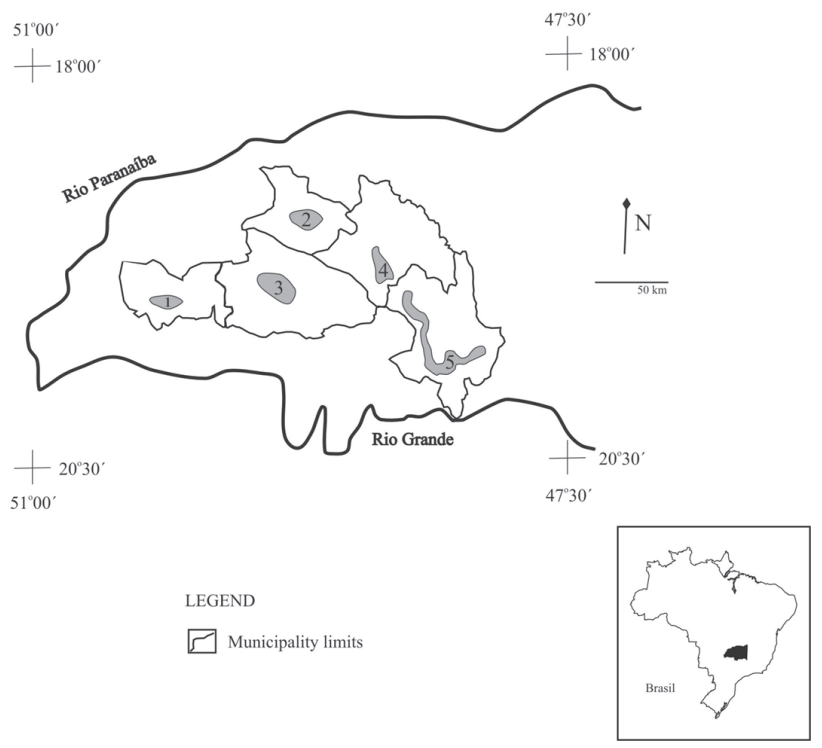

Fig. 1.-Map of the Triângulo Mineiro municipalities (Minas Gerais State, Brazil) illustrating location of the more important biota-bearing Bauru Group regions. 1, Campina Verde; 2, Monte Alegre de Minas; 3, Prata; 4, Uberlândia; 5, Uberaba.

records of dinosaurs are represented mainly by eggs and isolated bones.

The intention of this work is to summarize the current knowledge of the stratigraphy of the Upper Cretaceous fossil-bearing units of the Bauru Group from Triângulo Mineiro, and the composition of fauna and flora inferred from their assemblages.

\section{Geological and paleontological setting}

The Bauru Group is an important fossil-bearing unit in the Triângulo Mineiro region that ranges in age from Turonian to late Maastrichtian (fig. 2). According to Fernandes \& Coimbra (1996) the group comprises a southeastward-thinning sucession of continental rocks nowadays exposed in modern drainages throughout South-Central Brazil, which conformably overlies magmatic rocks of the Jurassic-Cretaceous Serra Geral Formation (São Bento Group, Paraná Basin). The Bauru Group has been a source of dinosaur and other fossil vertebrates (figs. 3A-K), invertebrates, and plants that have been discovered and collected since the early part of the 20th century.

Fernandes \& Coimbra (1996) included the Adamantina, Uberaba, and Marília formations (ascending order) in the Bauru Group; this stratigraphic arrangement is widely accepted and used in this study.

\section{Adamantina Formation}

This unit was established by Soares et al. (1980) referring to the continental deposits which unconformably overlie the Serra Geral Formation (São Bento Group, Paraná Basin). The Adamantina Formation crops in the States of Goiás, São Paulo and in the Triângulo Mineiro region, Minas Gerais State. Sediments are fluvial-lacustrine reddish clays and sands, deposited during warm and humid climatic events (Suguio \& Barcelos, 1983). Based primarily on its vertebrate fossil contents, it is assumed that the Adamantina sediments were deposited during the Turonian-Santonian (Dias-Brito et al., 2001). The geology of the Adamantina Formation in Triângulo Mineiro region has been studied by several authors (Barcelos, 1984; Ferreira-Júnior, 1996; Goldenberg \& Garcia, 2000). The formation's maximum thickness is close to $200 \mathrm{~m}$.; it is composed of medium-grained sandstones, shales, and conglomerates that are purple, dark red and brownish in color, deposited in a fluvial environment under braided regime (Barcelos, 1984).

\section{Fossil content}

The Adamantina Formation has a remarkable faunal record of essentially vertebrate taxa. Dinosaur remains are the most representative record. Among sauropods, specimens recovered include the eutitanosaurian Aeolosaurus (Almeida et al., 2004), isolated caudal vertebrae, and ribs of Titanosauria from the Prata area (Marinho, 2003; fig. 3J). Recently at the Prata Site was described a new titanosaur Maxakalisaurus topai by Kellner et al. (2006). Abelisaurid, carcharodontosaurid, and theropod indet. isolated attributed to teeth were reported by Marinho (2003), and Candeiro et al. (2003, 2006), from this unit near the Boa Vista Hill (Prata Town). The fossil-bearing horizons of the Adamantina Formation at Boa Vista Hill have yielded freshwater taxa including turtles and crocodyliforms (Marinho, 2003; Candeiro et al., 2003).

\section{Uberaba Formation}

This unit, defined by Barbosa (1934), is one of the most homogeneous and characteristic units of the Bauru Group. The formation has restricted exposures in Triângulo Mineiro region where interdigitates with the Adamantina Formation. Litholog- 
Table 1.-List of biota content from the Late Cretaceous Triângulo Mineiro region (Minas Gerais State, Brazil). Localities are shown in figure 1

\begin{tabular}{|c|c|c|c|}
\hline Taxa & Locality & Stratigraphy & Selected References \\
\hline \multicolumn{4}{|l|}{ INVERTEBRATES } \\
\hline \multicolumn{4}{|l|}{ Gastropoda } \\
\hline $\begin{array}{l}\text { Ostracods } \\
\text { Llyocypris setembrinopetrii } \\
\text { Amblyochara } \\
\text { Llyocpris sp. } 1 \\
\text { Neuquenocypris minor mineira } \\
\text { Virgatocypris mezzalirai } \\
\text { Altanicupris australis } \\
\text { Lycopterocypris angulata } \\
\text { Candonopsis sp. } \\
\text { Gen. et sp. Indet } 1 \\
\text { Gen. et sp. Indet } 1\end{array}$ & $\begin{array}{l}\text { Uberaba } \\
\text { Uberaba } \\
\text { Uberaba } \\
\text { Uberaba } \\
\text { Uberaba } \\
\text { Uberaba } \\
\text { Uberaba } \\
\text { Uberaba } \\
\text { Uberaba } \\
\text { Uberaba }\end{array}$ & $\begin{array}{l}\text { Ponte Alta Mb., Marília Fm. } \\
\text { Ponte Alta Mb., Marília Fm. } \\
\text { Ponte Alta Mb., Marília Fm. } \\
\text { Ponte Alta Mb., Marília Fm. } \\
\text { Ponte Alta Mb., Marília Fm. } \\
\text { Ponte Alta Mb., Marília Fm. } \\
\text { Ponte Alta Mb., Marília Fm. } \\
\text { Ponte Alta Mb., Marília Fm. } \\
\text { Ponte Alta Mb., Marília Fm. } \\
\text { Ponte Alta Mb., Marília Fm. }\end{array}$ & $\begin{array}{l}\text { Dias-Brito et al. (2001) } \\
\text { Dias-Brito et al. (2001) } \\
\text { Dias-Brito et al. (2001) } \\
\text { Dias-Brito et al. (2001) } \\
\text { Dias-Brito et al. (2001) } \\
\text { Dias-Brito et al. (2001) } \\
\text { Dias-Brito et al. (2001) } \\
\text { Dias-Brito et al. (2001) } \\
\text { Dias-Brito et al. (2001) } \\
\text { Dias-Brito et al. (2001) }\end{array}$ \\
\hline $\begin{array}{l}\text { Viviparid } \\
\text { Viviparus sp. B } \\
\text { Viviparus souzai } \\
\text { Physidae } \\
\text { Physa aridi }\end{array}$ & $\begin{array}{l}\text { Uberaba } \\
\text { Campina Verde } \\
\text { Uberaba }\end{array}$ & $\begin{array}{l}\text { Serra da Galga Mb., Marília Fm. } \\
\text { Serra da Galga Mb., Marília Fm. } \\
\text { Serra da Galga Mb., Marília Fm. }\end{array}$ & $\begin{array}{l}\text { Senra (2002) } \\
\text { Senra (2002) } \\
\text { Senra (2002) }\end{array}$ \\
\hline $\begin{array}{l}\text { Bivalvia } \\
\text { Florencia peiropolensis } \\
\text { Anodontites (Anodontites) pricei } \\
\text { Sphaerium (Musculium) sp. }\end{array}$ & $\begin{array}{l}\text { Uberaba } \\
\text { Uberaba } \\
\text { Uberaba }\end{array}$ & $\begin{array}{l}\text { Serra da Galga Mb., Marília Fm. } \\
\text { Serra da Galga Mb., Marília Fm. } \\
\text { Serra da Galga Mb., Marília Fm. }\end{array}$ & $\begin{array}{l}\text { Mezzalira (1974) } \\
\text { Mezzalira (1974) } \\
\text { Senra (2002) }\end{array}$ \\
\hline \multicolumn{4}{|l|}{ VERTEBRATES } \\
\hline $\begin{array}{l}\text { Fishies } \\
\text { Characiform } \\
\text { Siluriform } \\
\text { Perciform } \\
\text { Osteichthyes indet. }\end{array}$ & $\begin{array}{l}\text { Uberaba } \\
\text { Uberaba } \\
\text { Uberaba } \\
\text { Uberlándia, Uberaba }\end{array}$ & $\begin{array}{l}\text { Serra da Galga Mb., Marília Fm. } \\
\text { Serra da Galga Mb., Marília Fm. } \\
\text { Serra da Galga Mb., Marília Fm. } \\
\text { Ponte Alta and Sena da Galga Mbs, } \\
\text { Marília Fm. }\end{array}$ & $\begin{array}{l}\text { Gayet and Brito (1989) } \\
\text { Gayet and Brito (1989) } \\
\text { Gayet and Brito (1989) } \\
\text { Bertini et al. (1993), Fernandes (1998) }\end{array}$ \\
\hline $\begin{array}{l}\text { Frog } \\
\text { Baurubatrachus pricie }\end{array}$ & Uberaba & Serra da Galga Mb., Marília Fm. & Baez and Peri (1989) \\
\hline $\begin{array}{l}\text { Turtles } \\
\text { Chelonia indet. } \\
\text { Cambaremys langertoni }\end{array}$ & $\begin{array}{l}\text { Uberaba } \\
\text { Uberaba }\end{array}$ & $\begin{array}{l}\text { Serra da Galga Mb., Marília Fm. } \\
\text { Serra da Galga Mb., Marília Fm. }\end{array}$ & $\begin{array}{l}\text { Bertini et al. (1993), Marinho (2003) } \\
\text { França and Langer (2005) }\end{array}$ \\
\hline $\begin{array}{l}\text { Lepidosaur } \\
\text { Pristiguana brasiliensis }\end{array}$ & Uberaba & Serra da Galga Mb., Marília Fm. & Estes and Price (1973) \\
\hline $\begin{array}{l}\text { Crocodiles } \\
\text { Itasuchusjesuinoi } \\
\text { Peirosaurus torminii } \\
\text { Crocodylia indet. }\end{array}$ & $\begin{array}{l}\text { Uberaba } \\
\text { Uberaba } \\
\text { Uberaba }\end{array}$ & $\begin{array}{l}\text { Serra da Galga Mb., Marília Fm. } \\
\text { Serra da Galga Mb., Marília Fm. } \\
\text { Serra da Galga Mb., Marília Fm. }\end{array}$ & $\begin{array}{l}\text { Price }(1955) \\
\text { Price (1955) } \\
\text { Avilla (2002), Candeiro et al., (2003) }\end{array}$ \\
\hline \multicolumn{4}{|l|}{ Dinosaurs } \\
\hline $\begin{array}{l}\text { Sauropods } \\
\text { N. sp. et gen. } \\
\text { "Megalodontidae" }\end{array}$ & $\begin{array}{l}\text { Uberaba } \\
\text { Uberaba }\end{array}$ & $\begin{array}{l}\text { Uberaba Fm. } \\
\text { Uberaba Fm., Sena da Galga Mb., } \\
\text { Marília Fm. }\end{array}$ & $\begin{array}{l}\text { Santucci (2002) } \\
\text { Magalháes-Ribeiro (2002a, b) }\end{array}$ \\
\hline $\begin{array}{l}\text { Titanosauria } \\
\text { N. sp. et gen. } \\
\text { Aeolosaurus }\end{array}$ & $\begin{array}{l}\text { Campina Verde, Monte } \\
\text { Alegre, Prata, Uberaba } \\
\text { Uberaba } \\
\text { Prata, Uberaba }\end{array}$ & $\begin{array}{l}\text { Uberaba Fm., Sena da Galga Mb., } \\
\text { Marília Fm. } \\
\text { Serra da Galga Mb., Marília Fm. } \\
\text { Serra da Galga Mb., Marília Fm., } \\
\text { Adamantina Formation }\end{array}$ & $\begin{array}{l}\text { Powell }(1986,1987,2003), \\
\text { Marinho }(2003) \\
\text { Santucci }(2002) \\
\text { Santucci (2002), Almeida et al. (2004) }\end{array}$ \\
\hline \multicolumn{4}{|l|}{ Theropods } \\
\hline Theropoda indet. & Prata, Uberaba & $\begin{array}{l}\text { Serra da Galga Mb., Marília Fm., } \\
\text { Adamantina Formation }\end{array}$ & $\begin{array}{l}\text { Kellner (1996), Franco (1999), } \\
\text { Candeiro (2002), Marinho (2003) }\end{array}$ \\
\hline Abelisauridae & Prata, Uberaba & $\begin{array}{l}\text { Serra da Galga Mb., Marília Fm., } \\
\text { Adamantina Formation }\end{array}$ & Candeiro (2002), Marinho (2003) \\
\hline Carcharodontosauri dae & Prata, Uberaba & $\begin{array}{l}\text { Serra da Galga Mb., Marília Fm., } \\
\text { Adamantina Formation }\end{array}$ & Candeiro (2002), Marinho (2003) \\
\hline
\end{tabular}


Table 1.-List of biota content from the Late Cretaceous Triângulo Mineiro region (Minas Gerais State, Brazil). Localities are shown in figure 1 (continued)

\begin{tabular}{|c|c|c|c|}
\hline Taxa & Locality & Stratigraphy & Selected References \\
\hline \multicolumn{4}{|l|}{ FLORA } \\
\hline $\begin{array}{l}\text { Charophyta } \\
\text { Feistiella cf. globosa } \\
\text { Feistiella cf. costata } \\
\text { Sphaerochara latifasciata } \\
\text { Nitellopsis? sp. } \\
\text { Gobichara (Pseudoharrisichara) groeberi } \\
\text { Gobichara (Pseudoharrisichara) sp. } \\
\text { Chara tomentosa }\end{array}$ & $\begin{array}{l}\text { Uberaba } \\
\text { Uberaba } \\
\text { Uberaba } \\
\text { Uberaba } \\
\text { Uberaba } \\
\text { Uberaba } \\
\text { Uberaba }\end{array}$ & $\begin{array}{l}\text { Ponte Alta Mb., Marília Fm. } \\
\text { Ponte Alta Mb., Marília Fm. } \\
\text { Ponte Alta Mb., Marília Fm. } \\
\text { Ponte Alta Mb., Marília Fm. } \\
\text { Ponte Alta Mb., Marília Fm. } \\
\text { Ponte Alta Mb., Marília Fm. } \\
\text { Ponte Alta Mb., Marília Fm. }\end{array}$ & $\begin{array}{l}\text { Dias-Brito et al. (2001) } \\
\text { Dias-Brito et al. (2001) } \\
\text { Dias-Brito et al. }(2001) \\
\text { Dias-Brito et al. }(2001) \\
\text { Dias-Brito et al. }(2001) \\
\text { Dias-Brito et al. }(2001) \\
\text { Dias-Brito et al. }(2001)\end{array}$ \\
\hline $\begin{array}{l}\text { Pteridophyta } \\
\text { Marsilea? }\end{array}$ & Uberaba & Serra da Galga Mb., Marília Fm. & Senra and Silva-Silva \\
\hline
\end{tabular}

ically, these strata are composed of freshwater limestones, sandstones, and basal conglomerate, all cemented by calcium carbonate and vulcanoclastic sediments (Barcelos, 1984); green sandstones with thin layers of light red sandstones are common within the succession. The formation's maximum thickness is close to $140 \mathrm{~m}$ (Fernandes \& Coimbra, 1996), and is considered Coniacian-Santonian by Dias-Brito et al. (2001) in age

\section{Fossil content}

The Uberaba Formation has yielded only disarticulated dinosaur specimens. Santucci (2002) noted that sauropod remains from the Uberaba Formation represent possibly basal titanosaurs. One dinosaur nest was reported near the Peirópolis district of the Uberaba Town by Barbosa et al. (1970), which Campos \& Bertini (1985) attributed to an ornithischian taxon (fig. 3H-I). However, Kellner et al. (1998) attributed this record to a theropod dinosaur.

\section{Marília Formation}

This is the youngest unit of the Bauru Group and was first named by Almeida \& Barbosa (1953). The Marília Formation is exposed in the Goiás and São Paulo States and in the Triângulo Mineiro region. The Marília Formation consists in fine to medium sandstones intercalated by conglomerate levels. The sandstones are cemented and contain concretions of calcium carbonate (Fúlfaro \& Barcelos, 1991). The formation thickness is estimated to be $180 \mathrm{~m}$ in Minas Gerais State (Fernandes \& Coimbra, 1996). Dias-Brito et al. (2001) suggested an Upper Maastrichtian age for the Marília Formation.
Barcelos (1984) subdivided the Marília Formation into three members: two restricted in the Triângulo Mineiro region, the Ponte Alta \& Serra da Galga Members, and the Echaporã Member that crops in the Goiás and São Paulo States. The Ponte Alta Member is characterized sedimentologically as a "calcareous white member" composed of thin and medium calcareous horizons with pebbles and calcareous nodules deposited in alkaline lakes ("playalake" type) oversaturated with calcium bicarbonate (Garrido et al., 1992). The upper Serra da Galga Member is characterized as a "member of white limestone and conglomerate" composed of conglomerate and thin to medium limestones, with a bleached coloration in a feldspar matrix (Garrido et al., 1992). According to Suguio (1973, 1980), both members were formed in a moderately dry climate that would have favored fossil preservation.

\section{Fossil content}

Among the aquatic vertebrate taxa are: Lepisosteiformes, Characiformes, Siluriformes, Perciformes and Osteichthyes indet. "Leptodactylidae" species are represented only by Baurubatrachus pricei (Baez \& Peri, 1989), and represents the only known anuran from the Bauru Group in Triângulo Mineiro region. From the Peirópolis Site (Uberaba) crocodyliform species referred to as peirosaurids such as Peirosaurus tormini and Itasuchus jesuinoi (Price, 1955), and Uberabasuchus terrificus (Carvalho et al., 2004) are known (sense Avilla, 2002; Carvalho et al., 2004; fig. 3A-G). Podocnemine turtles were recorded by Bertini et al. (1993). A new turtle Cambaremys langertoni was recently described by França \& Langer (2005) from Peirópolis Site. Dinosaurs comprise the largest, 
most abundant and diverse vertebrates found at the Peirópolis Site (Kellner \& Campos, 2000; Marinho et al., 2003; fig. 3K). Teeth remains of titanosaurs, abelisaurid and carcharodontosaurid occur frequently at Uberaba. Recently, Novas et al. (2005) reported the first maniraptoran dinosaur remain of the Bauru Group from Peirópolis area. Titanosaurs include Baurutitan britoi and Aeolosaurus sp. (Bertini et al., 2000; Kellner et al., 2005). One dinosaur nest was reported near the Mangabeira district of the Uberaba Town (Price 1951), which was attributed as "Hypselosaurus" sp. (Bertini et al., 1993). Recently, "Megaloolithidae" egg shells were reported from the Peirópolis area (MagalhãesRibeiro 2002a, b).

Freshwater invertebrates have been reported from the Marília Formation (see table 1). Mollusks are well represented in the Uberaba municipality and include: Llyocypris setembrinopetrii, Llyocpris sp. 1, Neuquenocypris minor mineira, Virgatocypris mezzalirai, Altanicupris australis Lycopterocypris angulata, Candonopsis sp, and two new species. Llyocypris argentinensis, I. wichmanni, and Neuquenocypris minor correlate this biota to that from the Neuquen Basin, Argentina (Dias Brito et al., 2001) and support the temporal assignment (see table 1). The charophyte assemblage represented by Feistiella cf. globosa, Feistiella cf. costata, Sphaerochara latifasciata, Nitellopsis ? sp., Gobichara (Pseudoharrisichara) groeberi, Gobichara (Pseudoharrisichara) sp., and Chara tomentosa, has a broad distribution in the Bauru Group (Dias Brito et al., 2001).

\section{Discussion}

The Triângulo Mineiro biota is important for several reasons, principally in terms of stratigraphical interest, because it ranges in age from the Turonian to the late Maastrichtian. It is also historically important because of many early discoveries of Late Cretaceous vertebrates from Central Brazil, including the first dinosaur eggs ever found in Brazil. Crocodiles and dinosaurs are the most common vertebrates found in Triângulo Mineiro region. Titanosaurid dinosaurs are the most abundant, but abelisaurid and carcharodontosaurid theropods are also represented. Our knowledge of Triângulo Mineiro biota has been greatly improved in the last five years through the exploration of a number of rich localities at Uberaba and Prata

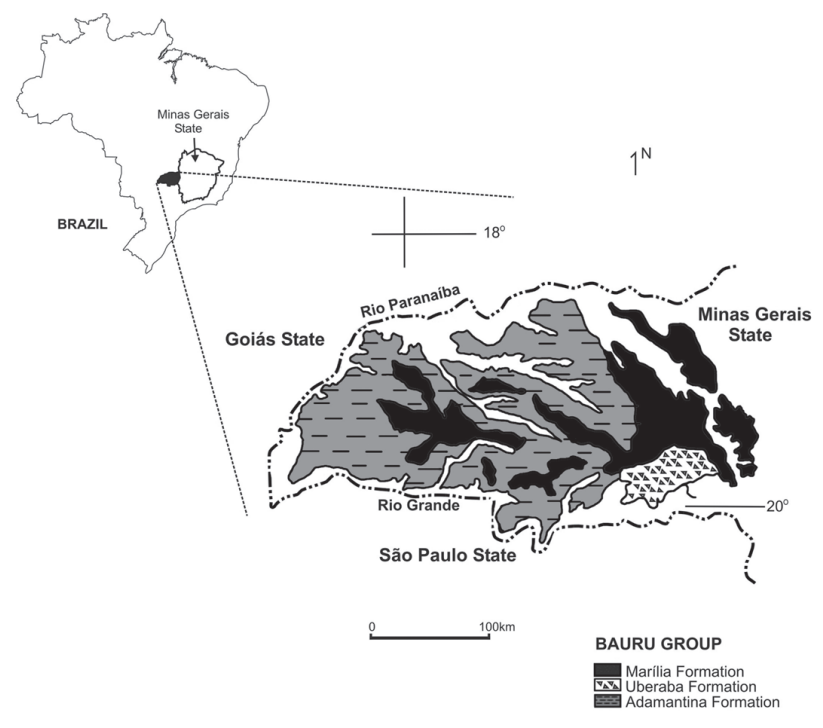

Fig. 2.-Geological map of the Triângulo Mineiro region, Minas Gerais State, Brazil (modified from Fernandes and Coimbra, 1996).

municipalities and due to the identification or revision of interesting specimens: 39 taxa have been reported in recent years. New taxa include abelisaurid and carcharodontosaurid theropods, and the eutitanosaurian Aeolosaurus, from the Adamantina and Marília Formations. Additional dinosaur specimens have been re-described or revised in detail in recent years (Marinho, 2003; Powell, 2003; Marinho \& Candeiro, 2005), including remains from Marília Formation, such as titanosaur osteoderms and caudal vertebrae, and "Megalolithidae" eggs. Most of the vertebrate material from Triângulo Mineiro is fragmentary, but specimens of Peirosaurus, Itasuchus, Aeolosaurus, Abelisauridae and Carcharodontosauridae have diagnostic features such as wrinkles on the crown tooth. For the ichnological record, dinosaur eggs of "Megalolithidae" are known from the sites of the Uberaba municipality. Finally, the Late Cretaceous mollusk and charophytae records of Uberaba are among the most representative in the Bauru Group and have yielded several species also known from Patagonia (Leanza et al., 2004).

The similarity between the biota contents of the Turonian-Maastrichtian units of the Triângulo Mineiro region to the Patagonian units (Bajo Barreal Formation, middle Cenomanian-Turonian; Angostura Colorada, Late Senonian; Bajo de La Carpa Formation, Santonian; Los Alamitos, Late Campanian; Allen Formation, middle Maastrichtian), suggests 
A

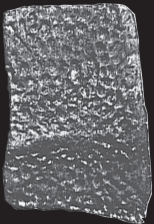

B

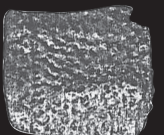

C

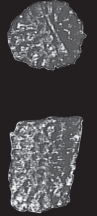

E

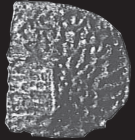

$\mathbf{F}$

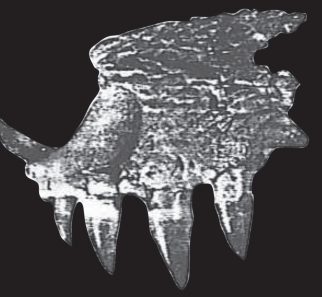

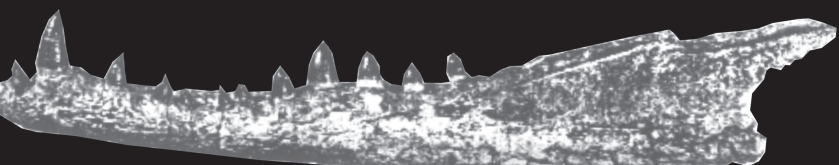

G

H
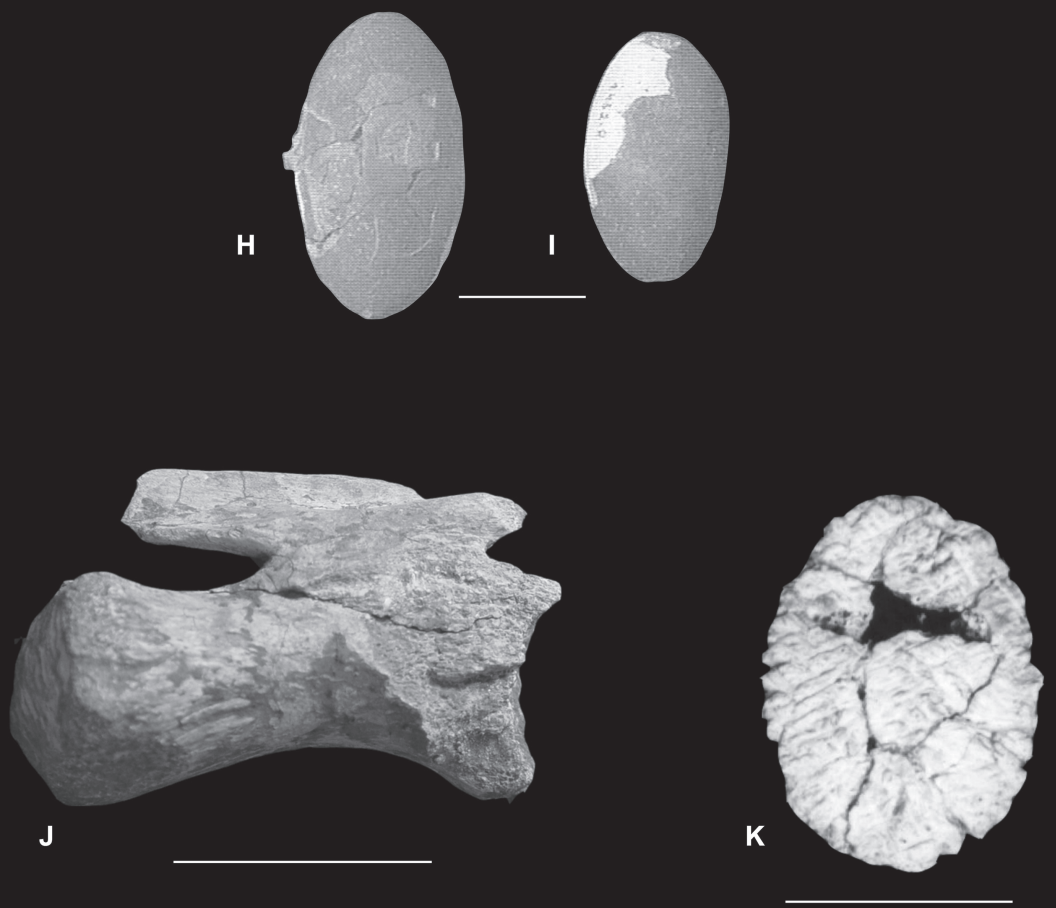

Fig. 3.-A-E, osteoderms and F, premasilla of left premaxilla of Peirosaurus tormini; $\mathrm{G}$, dentary of the Itasuchus jesuinoi; $\mathrm{H}$, I, dinosaur eggs from the Uberaba Formation; J, titanosaur caudal vertebra from Prata municipality; K, titanosaur osteoderm from Marília Formation of the Uberaba Municipality. (A-G, from Price, 1955; H, I, from Kellner and Campos, 2000; J, from Marinho, 2003; $\mathrm{K}$, from Marinho and Candeiro 2005). Scale bar in $A-F=2 \mathrm{~mm} ; \mathrm{G}=17 \mathrm{~mm} ; \mathrm{H}, \mathrm{I}=5 \mathrm{~mm} ; \mathrm{J}=10 \mathrm{~mm} ; \mathrm{K}=20 \mathrm{~mm}$. 
that by the early Late Cretaceous there was an interconnection between these realms. This is evidenced from the common presence of Carcharodontosauridae and Abelisauridae. The same geographical spreading pattern is evidenced by the crocodilian Peirosaurus tormini found both, in the Marília Formation in Brazil and in the Bajo de la Carpa Formation of Patagonia, where seems to appear as early as the Santonian stage.

It is difficult to determine whether this Brazilian biota is more related to African or Patagonian taxa from the middle Cretaceous. Comparison of the tetrapod assemblages from both areas is heavily biased. Most of the southern Patagonian ones well represented in the Triângulo Mineiro region (e.g. Aeolosaurus, Peirosaurus, ostracods) are currently considered as endemic. However, the similarity of carcharodontosaurid remains (from the Adamantina Formation, São Paulo State, Brazil) to the African biota may demonstrate their close relationship with African taxa. Another important implication concerns the distribution of the crocodile genus Itasuchus, which is found in the Santana Formation (Albian). The frequent occurrences of this genus in the Marília Formation indicate that this taxon was probably also extremely common during Upper Cretaceous.

\section{Conclusions}

The evaluation of the Triângulo Mineiro biota has revealed a wide diversity of taxa (e.g. mollusks, crocodilians, dinosaurs) and ostracods. This biota, discovered in the formations of the Bauru Group, spans from Turonian to late Maastrichtian. These sediments where deposited in eolian and fluviolacustrine environments.

The Triângulo Mineiro biota is similar to Argentinean Late Cretaceous faunal assemblages, such as those from Patagonian deposits. The Triângulo Mineiro biota also shares compositional features with Cretaceous continental tetrapod faunas from more distant Gondwanan localities (e.g. continental Africa), indicating a common Gondwanan origin.

\section{ACKNOWLEDGMENTS}

I gratefully acknowledge to Sarah Earland (University of Portsmouth) and Lílian P. Bergqvist (Departamento de Geologia, Universidade Federal do Rio de Janeiro) and Federidco Fanti (Université Bologna, Italy) for the comments about the text.

\section{References}

Almeida, F. F. M. \& Barbosa, O. (1953). Geologia das quadrículas de Piracicaba e Rio Claro. Bol. Div. Geol. Mineral, 143: 1-96.

Almeida, E. B., Avilla, L. S. \& Candeiro, C. R. A. (2004). Restos caudais associados a Titanosauridae do Cretáceo Superior da Formação Adamantina, Bacia Bauru, Município do Prata - MG. Rev. Bras. Paleontol., 7: 239-244.

Avilla, L. S. (2002). Análise filogenética dos Mesoeucrocodylia basais da América do Sul e a evolução do Gondwana (Archosauria: Crocodyliformes). Master Dissertation. Museu Nacional, Universidade Federal do Rio de Janeiro, $91 \mathrm{p}$.

Baez, A. M. \& Peri, S. (1989). Baurubatrachus pricei, nov. gen. et sp., un Anuro del Cretacico Superior de Minas Gerais, Brazil. An. Acad. Bras. Ciências, 61: 447-458.

Barbosa, O. (1934). Resumo da Geologia do Estado de Minas Gerais. Serviço Geológico, 3: 1-44.

Barbosa, O., Braun, O. P. G., Dyer, R. C. \& Cunha, C. A. B. R. (1970). Geologia da região do Triângulo Mineiro. Bol. Depart. Nac. Prod. Mineral, 136: 36-39.

Barcelos, J. H. (1984). Reconstrução paleogeográfica da sedimentação do Grupo Bauru baseada na sua redefinição estratigráfica parcial em território paulista e no estudo preliminar fora do estado de São Paulo. Ph.D., Universidade Estadual Paulista/Rio Claro, 190 p.

Bertini, R. J., Marshall, L. G., Gayet, M. \& Brito, P. (1993). Vertebrate faunas from the Adamantina and Marilia formations (Upper Bauru Group, Late Cretaceous, Brazil). Neus Jahr. Geol. und Paläont. Abh, 188: 71-101.

Bertini, R. J., Santucci, R. M., Ribeiro, L. C. B. \& Arruda-Campos, A. C. (2000). Aeolosaurus (Sauropoda, Titanosauria) from Late Cretaceous of Brasil. XVI Jornadas Argentinas de Paleontologia de Vertebrados (San Luis), Actas, 1: 6.

Campos, D. A. \& Bertini, R. J. (1985). Ovos de dinossauro da formação Uberaba, Cretáceo Superior do estado de Minas Gerais. XI Congresso Brasileiro de Paleontologia, Fortaleza, Brasil. Boletim de Resumos, 1: 19.

Candeiro, C. R. A. (2002). Dentes de Theropoda da Formação Marília (Santoniano-Maastrichtiano), Bacia Bauru, Região de Peirópolis, Uberaba, Minas Gerais, Brasil. Master Dissertation. Departamento de Geologia, Universidade Federal do Rio de Janeiro, 136 p.

Candeiro, C. R. A., Marinho, T. S., Novais, G. T., Franco, A. C., Albuquerque, J. A. C. \& Oliveira, E. C. (2003). Previously unreported result from the Upper Cretaceous of the Paleontological Site of Prata, Minas Gerais State, Brazil. III Simpósio Brasileiro de Paleontologia de Vertebrados, Rio de Janeiro, Brasil. Boletim de Resumos, 1: 20.

Candeiro, C. R. A., Santos, A. R., Rich, T., Marinho, T. S. \& Oliveira, E. C. (2006). Vertebrates fossils from the Adamantina Formation (Late Cretaceous), Prata Paleontological District, Minas Gerais State, Brazil. Geobios, 39: 319-327. 
Carvalho, I. S., Ribeiro, L. C. B. \& Avilla, L. S. (2004). Uberabasuchus terrificus sp. nov., a new Crocodylomorpha from the Bauru Basin (Upper Cretaceous), Brazil. Gond. Res, 7: 975-1002.

Dias-Brito, D., Musacchio, E. A., Castro, J. C., Maranhão, M. S. A., Suárez, J. M. \& Rodrigues, R. (2001). Grupo Bauru: uma unidade continental do Cretáceo do Brasil - concepções baseadas em dados micropaleontológicos, isotópicos e estratigráficos. Rev. Paléobiol, 20: 245-304.

Estes, R. \& Price, L. I. (1973). Iguanid lizard from the Upper Cretaceous of Brazil. Science, 180: 748-751.

Fernandes, L. A. (1998). Estratigrafia e evolução geológica da parte oriental da Bacia Bauru (Ks, Brasil). Ph.D. Universidade de São Paulo, 226 p.

Fernandes, L. A. \& Coimbra, A. M. (1996). A Bacia Bauru (Cretáceo Superior, Brasil). An. Acad. Bras. Ciênc., 68: 195-105.

Ferreira Junior, P. D. (1996). Modelo Deposicional e evolução Diagenética da Formação Uberaba. Cretáceo Superior da Bacia do Paraná, na Região do Triângulo Mineiro. Master Dissertation. Universidade Federal de Ouro Preto, $176 \mathrm{p}$.

França, M. A. G. \& Langer, M. C. (2005). A new freshwater turtle (Reptilia, Pleurodira, Podocnemidae) from the Upper Cretaceous (Maastrichtian) of Minas Gerais, Brazil. Geodiversitas, 27: 391-411.

Franco, A. C. (1999). Dentes teropodomorfos do Cretáceo Superior da Bacia do Paraná. Análise em microscopia eletrônica de varredura. Master Dissertation. Universidade Estadual Paulista/Rio Claro, 109 p.

Fúlfaro, V. J. \& Barcelos, J. H. (1991). Grupo Bauru no Triângulo mineiro: uma nova visão litoestratigráficas. II Simpósio de Geologia do Sudeste, Rio Claro, Brasil, Boletim de Resumos, 1: 59-66.

Garrido, A. E., Ferreira, A. M. \& García, A. J. V. (1992). Estratigrafia e sedimentologia do Grupo Bauru em Peirópolis Município de Uberaba, Minas Gerais. Rev. Esc. Minas, 45: 112-114.

Gayet, M. \& Brito, P. M. (1989). Ichtyofaune Nouvelle du Crétacé Supérieur du Groupe Bauru (États de São Paulo et Minas Gerais, Brésil). Geobios, 22: 841847.

Goldberg, K. \& García, A. J. V. (2000). Palaeogeography of the Bauru Group, a dinosaur-bearing Cretaceous unit, northeastern Paraná Basin, Brazil. Cret. Res., 21: 241-254.

Kellner, A. W. A. (1996). Remarks on Brazilian dinosaurs. Memoirs of the Queensland Museum, 39: 489-532.

Kellner, A. W. A., Campos, D. A., Azevedo, S. A. \& Carvalho, L. B. (1998). Theropod dinosaur eggs from the Continental Upper Cretaceous of Minas Gerais, Brazil. J. Vert. Paleont., Abstract, 18: 55A.

Kellner, A. W. A. \& Campos, D. A. (2000). Brief Review of Dinosaur Studies and Perspectives in Brazil. An. Acad. Bras. Ciências, 72: 509-538.

Kellner, A. W. A., Campos, D. A. \& Trotta, M. N. F. (2005). Description of a titanosaurid caudal series from the Bauru Group, Late Cretaceous of Brazil. Arq. Mus. Nac., 63: 529-564.

Kellner, A. W. A., Campos, D. A., Azevedo, S. A. K., Trotta, M. N. F., Henriques, D. D., Craik, M. M. T. \& Silva, H. P. (2006). On a new titanosaur sauropod from the Bauru Group, Late Cretaceous of Brazil. Bol. Mus. Nac., Ser. Geol., 74: 1-32.

Leanza, H. A., Apesteguía, S., Novas, F. \& de la Fuente, M. (2004). Cretaceous terrestrial beds from the Neuquén Basin (Argentina) and their tetrapod assemblages. Cret. Res., 25: 61-87.

Magalhães-Ribeiro, C. M. (2002a). Ovo e cascas de ovos de dinossauros da região de Uberaba, Minas Gerais (Formação Marília, Bacia Bauru, Cretáceo, Superior). Ph.D., Departamento de Geologia, Universidade Federal do Rio de Janeiro, 205 p.

Magalhães-Ribeiro, C. M. (2002b). Ovo e fragmentos de cascas de ovos de dinossauros, provenientes da região de Peirópolis, Uberaba, Minas Gerais. Arq. Mus. Nac, 60: 223-228.

Marinho, T. S. (2003). As ocorrências fossilíferas do Cretáceo Superior nos Municípios do Prata e Monte Alegre de Minas, no Triângulo Mineiro. Undergraduate Monograph. Universidade Federal de Uberlândia, $20 \mathrm{p}$.

Marinho, T. S. \& Candeiro, C. R. A. (2005). Titanosur (Dinosauria: Sauropoda) osteoderms from the Maastrichtian of Uberaba, Minas Gerais State, Brazil. Gond. Res., 8: 473-477.

Marinho, T. S., Oliveira, E. C., Albuquerque, J. A., Ribeiro, L. C. B. \& Candeiro, C. R. A. (2003). Dinosaurs from Bauru Basin (Upper Cretaceous). XVII Congresso Brasileiro de Paleontologia, Brasília, Boletim de Resumos, 1: 322.

Mezzalira, S. (1974). Contribuição ao conhecimento da estratigrafia e paleontologia do Arenito Bauru. Bol. Instit. Geográf. Geol., 51: 1-163.

Novas, F. E., Borges Ribeiro, L. C. \& Carvalho, I. S. (2005). Maniraptoran theropod ungual from the Marília Formation (Upper Cretaceous), Brazil. Rev. Mus. Argent. Cienc. Nat. Bernardino Rivadavia, Paleont., 7: 31-36.

Powell, J. E. (1986). Revisión de los titanosáuridos de América del Sur. Ph.D., Universidad Nacional de Tucumán, $340 \mathrm{p}$.

Powell, J. E. (1987). Morfologia del esqueleto axial de los dinosaurios Titanosaurios (Saurischia, Sauropoda) del estado de Minas Gerais, Brasil. XX Congresso Brasileiro de Paleontologia, Rio de Janeiro, Brasil, Actas, 1: 155-171.

Powell, J. E. (2003). Revision of South American titanosaurid dinosaurs: Paleobiological, Paleobiogepgraphical and Phylogenetic aspects. Records of the Queen Victoria Museum, 111: 1-173.

Price, L. I. (1951). Ovo de dinossauro na formação Bauru, do estado de Minas Gerais. Notas Preliminares da Divisão de Geologia de Mineralogia, 53: 1-7.

Price, L. I. (1955). Novos crocodilideos dos Arenitos da Série Bauru, Cretáceo do estado de Minas Gerais. An. Acad. Bras. Ciências, 27: 487-498. 
Santucci, R. M. (2002). Revisão dos titanosaurideos do Cretáceo Superior do Brasil. Master Dissertation. Universidade Estadual Paulista/Rio Claro, 179 p.

Senra, M. C. E. (2002). Malacofauna dulçalqüicola do Cretáceo do Brasil. Ph.D., Departamento de Geologia, Universidade Federal do Rio de Janeiro, 132 p.

Senra, M. C. E. \& Silva-Silva, L. H. (1998). Presença de esporocarpos de pteridófitas na Formação Marília, Grupo Bauru, Cretáceo Superior de Minas Gerais. An. Acad. Bras. Ciências, 70: 380-381.

Soares, P. C., Landim, P. M. B., Fúlfaro, V. J. \& Sobreiro-Neto, A. F. (1980). Ensaio de caracterização estratigráfica do Cretáceo no Estado de São Paulo: Grupo Bauru. Rev. Bras. Geociências, 10: 177-185.
Suguio, K. (1973). Calcretes of the Bauru Group (Cretaceous), Brazil: petrology and geological significance. Ph.D., Universidade de São Paulo, 236 p.

Suguio, K. (1980). Fatores Paleoambientais e Paleoclimáticos e Subdivisão Estratigráfica do Grupo Bauru. Mesa Redonda sobre a Formação Bauru no estado de São Paulo e Regióes Adjacentes. Sociedade Brasileira de Geologia, Núcleo São Paulo, 5: 15-26.

Suguio, K. \& Barcelos, J. H. (1983). Calcretes of the Bauru Group (Cretaceous) Brazil: petrology and geological significance. Bol. Instit. Geociênc. Univ. São Paulo, 14: 31-47.

Recibido el 5 de septiembre de 2005 Aceptado el 13 de marzo de 2006 